\title{
АКТУАЛІЗАЦІЯ АНГЛОМОВНИХ ПРИКМЕТНИКІВ НА ПОЗНАЧЕННЯ МИСЛЕННСВИХ КАТЕГОРІЙ ТА ОСОБЛИВОСТІ ЇХ ВІДТВОРЕННЯ УКРАЇНСЬКОЮ МОВОЮ
}

У статті розгляуто семантичні характеристики англійських прикметників на позначення інтелектуальних властивостей і результатів розумової діяльності особистості, ядром лексико-семантичного поля яких виступає поняттєва категорія «мислення». Англійська мова, як і багато інших, накопичила великий лексичний потенціал для різних аспектів інтелектуальної сили й когнітивних умінь. У лінгвістичному аспекті охарактеризувати його можна на основі аналізу певного лексико-семантичного поля. Для виявлення словесних характеристик прикметників на позначення позитивних і негативних інтелектуальних властивостей визначено склад та структуру відповідного лексико-семантичного поля, проаналізовано семантичну структуру домінант виділених лексико-семантичних груп й особливості відображення конституентами групи інтелектуальних властивостей. За результатами аналізу установлено, що воно сформоване з відповідних лексико-семантичних груп, кожна 3 яких представлена полярними семантичними домінантами. Групу прикметників 3 позитивною конотацією репрезентують такі семантичні домінанти, як clever, intellectual, wise, thoughtful, informed, conceivable, rational, а 3 негативною - як stupid, unintellectual, fool, thoughtless, ignorant, obscure, irrational. Шляхом аналізу семантичної структури прикметників на позначення мисленнєвих категорій з'ясовано, що прикметники 3 негативною конотацією не мають сильно вираженого семантичного розгалуження, характеризуються більшою однорідністю, проте за кількісним складом не поступаються прикметникам із позитивною конотацією. Вивчення особливостей відтворення ментальних прикметників українською мовою дало змогу встановити, що їх переклад залежить від поєднуваності з іншими лексичними одиницями та мовного контексту. Започатковане дослідження лексико-семантичного поля прикметників на позначення розумово-мисленнєвої діяльності людини слугує підгрунтям для пояснення явищ полісемії й синонімії та антонімії, створення тематичних словників-тезаурусів.

Ключові слова: прикметники англійської мови, позначення мисленнєвої діяльності, лексико-семантичне поле, семантична домінанта, переклад українською мовою.

Вступ. Інтелект, розум, свідомість роблять людину унікальним створінням, уможливлюючи пізнання нею всього, що ії оточує. Цей феномен досліджується низкою наукових дисциплін: філософією, логікою, психологією, лінгвістикою тощо. Поняття розуму, інтелекту, мислення є ключовими в когнітивістиці. Розум та інтелект - це здатність людини мислити й регулювати своє ставлення до дійсності. При цьому інтелект відображає досягнутий рівень пізнавального розвитку особистості, що проявляється у сформованості пізнавальних функцій, у ступені засвоєння знань і слугує для успішного опанування людиною різних видів діяльності та адаптації в навколишній дійсності. Інтелектуальні якості людини визначаються готовністю до ефективного засвоєння знань і вмінь, а також відображають здатність індивіда до обробки різних видів інформації.

Усі прояви життя людини, зокрема й особливості іiі інтелектуальної діяльності відображаються в лексиці. Вивчення лексичних одиниць та їх семантики є одним з основних завдань сучасного мовознавства, оскільки саме через цей аспект розкривається комунікативна сутність мови, здатність мовців до комунікативної взаємодії та позначення понять. Семантика вважається одним із пріоритетних напрямів дослідження, оскільки ії покладено в основу всіх гуманітарних дисциплін і вона виступає спільним елементом у розкритті номінації, комунікації й когніції.

Роботи стосовно розгляду різних типів номінативних полів, у тому числі й лексикосемантичних (3. Н. Вердиева, I. В. Горохова, І. П. Ділай, О. В. Гулига та Є. І. Шендельс, Л. А. Новіков, Е. В. Шнайдер та ін.), посідають провідне місце в традиційній семантиці. У них подано визначення поля як об'єкта лінгвістичного аналізу, сформульовано критерії виділення поля, викладено загальні принципи його структурування. Водночас, незважаючи на досить глибоке висвітлення проблем семантики слова, низка питань у межах теорії поля залишається відкритою для обговорення. Лексико-семантичне поле «ннтелектуальна діяльність» стало предметом дослідження таких науковців, як Л. О. Нижегородцева-Кириченко, І. В. Горохова та

(C) Корнєва 3., 2020 
ін., у працях яких досить детально опрацьовано дієслова й іменники на позначення ментальної сфери індивіда.

Отже, актуальність започаткованої роботи зумовлена тим, що прикметники на позначення психічних та інтелектуальних властивостей або результатів розумової діяльності особистості, на відміну від ментальних дієслів й іменників, не виступали об'єктом окремого лінгвістичного дослідження. Нагальність дослідження ментальних прикметників визначається тим, що:

- по-перше, лексико-семантична група прикметників, які позначають інтелектуальні властивості, представлена досить широко в усіх мовах і має різні форми реалізації (літературна мова, просторіччя, діалекти);

- по-друге, одиниці, які виражають психічні та інтелектуальні властивості людини або характеризують результати іiі розумової діяльності, мають більш складне співвідношення 3 денотатом дійсності, ніж, наприклад, прикметники фізичних властивостей;

- по-третє, прикметники посідають особливе місце серед інших частин мови, оскільки, на відміну від дієслів, які характеризують людину опосередковано, прикметники безпосередньо вказують на іï ознаку, що сприймається як постійна властивість людини.

3 огляду на викладене вище, метою цієї праці є обгрунтування семантичних характеристик англійських прикметників, що формують лексико-семантичне поле. Їх ядром є поняттєва категорія «мислення» та встановлення особливостей їх перекладу українською мовою.

Результати та дискусії. Людина відрізняється від інших живих істот здатністю не лише мислити, але й висловлювати свої думки. Не дивно, що в процесі розвитку людської цивілізації 3'являлася лексика для номінації та характеристики й самого людського розуму. Англійська мова, як і багато інших, накопичила значний лексичний потенціал для позначення різних аспектів інтелектуальної сили та когнітивних умінь людини. У лінгвістичному аспекті це можна охарактеризувати за допомогою семантичних і смислових відносин між значеннями низки слів, об'єднаних навколо спільної логіко-смислової одиниці, інакше кажучи, на основі аналізу певного лексико-семантичного поля (ЛСП). Поле будується від мовних одиниць через їхні семантичні значення й систему таких значень, а від них - до семантичної структури мови; вихідними слугують логічні поняття категорії, котрі не мають відповідника в мові.

У цій статті аналізуємо ад'єктивне ЛСП, підгрунтям якого $є$ поняттєва категорія «мислення». Однак, оскільки сам процес мислення не є однорідним та відображає різні аспекти розумового потенціалу, а також ступінь розумового розвитку, то в мовній площині він характеризуватиметься кількома семантичними категоріями. Отже, за семантичними диференціаціями, ЛСП, що досліджується, можна поділити на такі лексико-семантичні групи (ЛСГ) із відповідними домінантами:

Mental - Розумовий (позитивна конотація); Clever - Розумний; Intellectual Інтелектуальний; Wise - Мудрий; Thoughtful - Поміркований; Informed - Поінформований; Conceivable - Зрозумілий; Rational - Раціональний; Mental - Розумовий (негативна конотація); Stupid - Дурний; Unintellectual - Неінтелектуальний; Fool - Нерозсудливий; Thoughtless Бездумний; Ignorant - Непоінформований; Obscure - Незрозумілий; Irrational - Нераціональний.

Як свідчать результати аналізу, ЛСГ Mental (позитивна конотація): Clever, Intellectual, Wise, Thoughtful, Informed, Conceivable, Rational виражають високий чи достатній ступінь оцінки розумової діяльності, а групи з домінантами Mental (негативна конотація): Stupid, Unintellectual, Fool, Thoughtless, Ignorant, Obscure, Irrational указують, відповідно, на низький, обмежений вияв інтелектуальних якостей. Потрібно зазначити, що мисленнєва категорія Mental може виражати й позитивну, і негативну оцінку, залежно від смислового значення в конкретному контексті.

Семантичний склад i характеристики прикметників із позитивною оцінкою інтелектуальних властивостей (Mental, Clever, Intellectual, Wise, Thoughtful, Informed, Conceivable, Rational) представлено на рис. 1. 


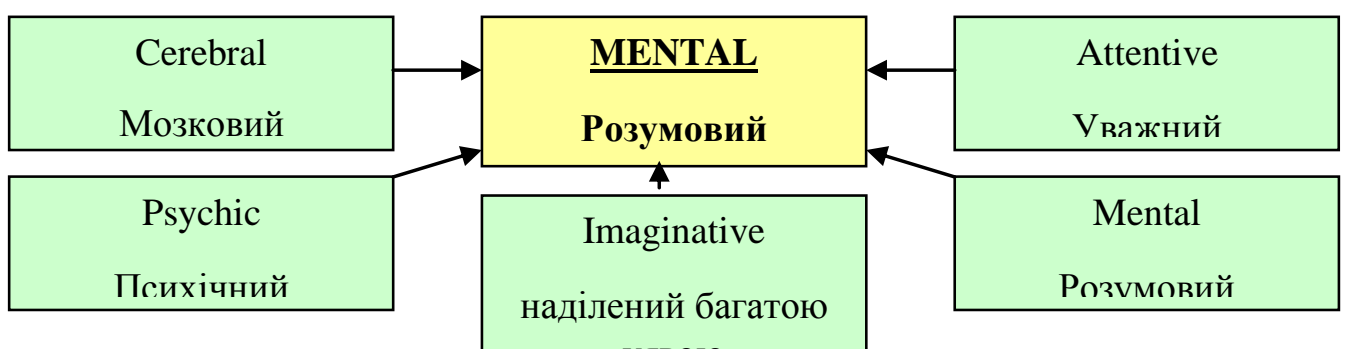

уявою

Рис. 1. Лексико-семантична група Mental

Як видно з рисунку, конституентів цієї ЛСГ об’єднує спільний смисл, «пов'язаний із роботою мозку» (involving the mind or an intellectual process). Характеристика моторних функцій мозку передається семами «cerebral», «psychic»: cerebral activity - розумова діяльність, cerebral circulation - мозковий кровообіг, psychic force - розумові здібності, psychic trauma - психічна травма. Що стосується продуктів роботи мозку - уваги, уяви, здатності мислити, розуміти, - то вони характеризуються семами «attentive», «imaginative», «mental»:

The news to which she was exceedingly attentive. - Новини, які вона слухала дуже уважно.

He found an imaginative solution to a long-standing problem. - Він знайшов оригінальне розв'язання старої проблеми.

Society exists only as a mental concept; in the real world there are only individuals. Суспільство є розумовою вигадкою; насправді ж існують лише окремі особистості.

До ЛСГ Mental також увійшла значна частина складних прикметників із компонентами «minded», «-headed»: clear-headed, fair-minded, noble-minded, right-minded, наприклад:

Economic times call for clear-headed decisions. - Економічне становище потребує прийняття розсудливих рішень;

I know that he is a fair-minded judge who correctly interprets laws. - Я знаю, щио він $\epsilon$ справедливим суддею, який правильно тлумачить закон.

До ЛСГ Clever увійшли прикметники зі значенням «кмітливий», «розумний», «здатний швидко й правильно реагувати» (displaying sharp intelligence or mental alertness), а також семи «clever», «smart», «ingenious», «shrewd» (рис. 2).

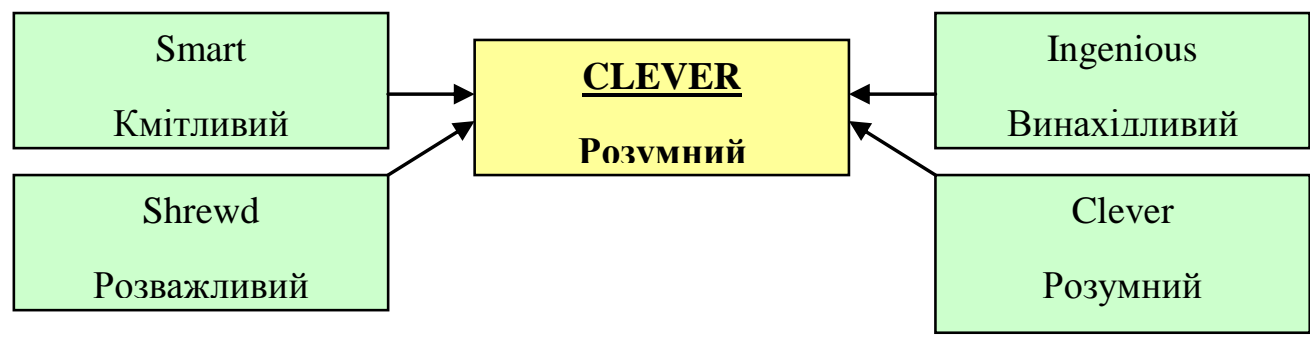

Рис 2. Лексико-семантична група Clever

Домінантне значення «clever» показує природну кмітливість, спроможність легко засвоїти інформацію, практичний склад розуму: He is not clever enough to do this task. - Bit недостатньо розумний для иъього завдання.

«Smart» указує на поєднання природної кмітливості з умінням зрозуміти, що вигідно об'єкту: She was smart to refuse. - У неї вистачило розуму відмовитися.

«Clever» може стосуватися будь-якого продукту інтелектуальної діяльності, навіть таких масштабних об'єктів, як теорії, книги, наукові роботи (clever piece of work, clever book), у той час, як «smart» уживається для характеристики немасштабних продуктів інтелекту - думок, здогадок, доводів тощо (smart argument, smart thoughts, smart analysis).

«Ingenious» характеризує кмітливість, винахідливість, здатність швидко зреагувати: $\mathrm{He}$ was ingenious to solve the problem so quickly. - Він проявив винахідливість $і$ дуже швидко розв'язав проблему. An ingenious contrivance - оригінальний винахід.

Прикметник «shrewd» означає здатність практично застосувати набуту інформацію: Judging from the state of his company, he is quite a shrewd businessman. - Судячи зі стану, у якому перебуває фірма, він є досить розважливим бізнесменом; A shrewd reasoning-мудре пояснення. 
Отже, «smart», «ingenious», «shrewd» становлять семантично вужчі, спеціалізовані значення домінантної лексеми «сlever», входячи при цьому до компонентів ії̈ значень.

ЛСГ Intellectual об'єднує ЛСВ зі спільним значенням «наділений гострим розумом», «обізнаний» (appealing to or characteristic of people with a developed intellect), що передається семами «intelligent» та «intellectual» (рис. 3).

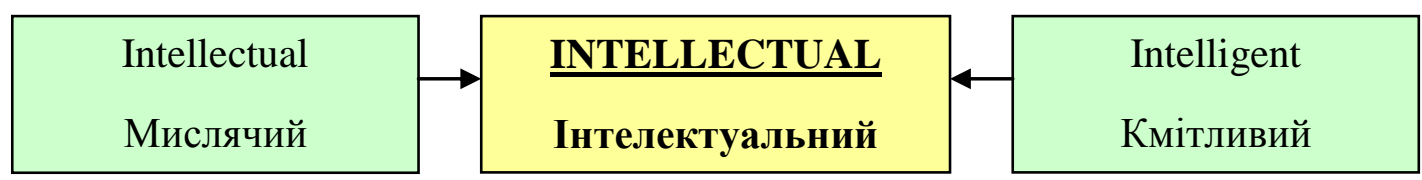

Рис. 3. Лексико-семантична група Intellectual

«Intelligent» указує на розум, що розвився в результаті утворення або впливу культурного середовища й здатен до тонкого та глибокого аналізу складних ситуацій, до прийняття рішень, які враховують усі деталі оточення. «Intelligent» також часто імплікує високий ступінь розуміння, спроможність тверезо мислити та усвідомлювати: An intelligent person is thought to be exceptionally good at what he does, and finds solutions to the most tricky and difficult of problems. - Вважається, щзо кмітлива людина винятково добре знає свою справу та знаходить розв'язання навіть найскладніших проблем.

«Intellectual» дає ширшу характеристику - не лише ступінь розуміння, але й здатність набувати вищих форм знань. «Intellectual» уключає розум, розуміння, розсудливість, уяву, власне інтелект: intellectual person - мисляча людина.

Прикметник «Intellectual» також уживається для характеристики явищ і процесів, які стосуються саме мислення, а не до емоційної сфери (relating to the intellect, as opposed to the emotions): Emotions kill your intellectual productivity; if we were machines running mechanical tasks, our productivity would be high. - Eмоиіï вбивають розумову продуктивність; як би ми були машинами, що автоматично виконують завдання, наша продуктивність була б вищою.

Прикметники, що увійшли до ЛСГ Wise, об'єднані семантичною характеристикою «мудрий», «розсудливий» (possessing, showing, or prompted by wisdom or discernment). Вони передають і природний розум, і мудрість, набуту життєвим досвідом: He said: «Just be yourself, write from the heart, and don't let anyone censor you». It was a wise piece of advice. - Він сказав: «Будь собою, пиши від серия $і$ не дозволяй нікому тебе критикувати». Це була мудра порада.

До групи 3 домінантою Thoughtful увійшли лексичні одиниці, які характеризують здатність мислити, роздумувати, міркувати, бути уважним (showing careful thought):

He had always been thoughtful of his health even in his pleasures. - Він завжди дуже турбувався про своє здоров'я, навіть коли розважався; He became thoughtful about religion. - Biн став уважно ставитися до релігіï.

Прикметники із семою Thoughtful характеризують людину, яка занурена у свої думки, щось обмірковує (occupied with or given to thought; contemplative, reflective): There were a lot of people on the street but Dale's thoughtful face said that he did not want to stop and speak to anyone. - Людей на вулиці було досить багато, але задумливе обличчя Дейла говорило про те, щяо він не хоче зупинятися й розмовляти з кимось; She was thoughtful for a while. - Вона задумалася на хвилинку.

Thoughtful указує також на готовність задовольнити фізичні потреби іншої людини, створити для неї матеріальні зручності (considerate in the treatment of other people): to be thoughtful of others - думати, турбуватися про інших, not very thoughtful of уоu - ви не дуже уважні.

Складові частини групи Informed об'єднані спільною ознакою «той, що володіє інформацією» (having or prepared with information or knowledge), і включають компоненти значень «обізнаний» («knowing»), «освічений» («educated») (рис. 4).

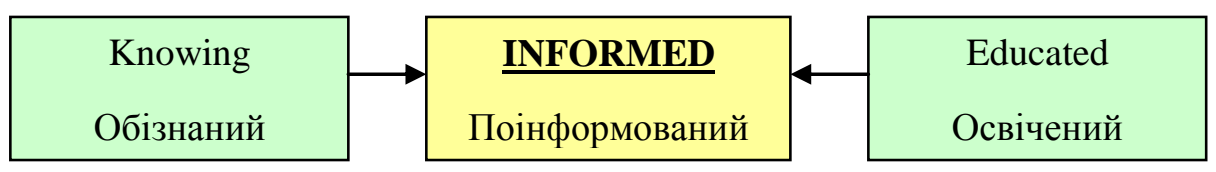

Рис. 4. Лексико-семантична група Informed 
Прикметники із семою «knowing» передбачають здатність практично застосувати набуту інформацію: He is the most knowing of all the staff. - Він найбільш компетентний із всього персоналу.

«Knowing» указує також на володіння інформацією або знаннями, що є недоступними для інших (a knowing glance - погляд знаючої людини), а також означає свідомі та виважені дії (a knowing attempt to defraud - свідома спроба шахрайства).

«Educated» характеризує людину культурну, із широким світоглядом та глибокими знаннями, що були набуті в результаті розвитку або освіти: He was an educated man with plenty of skills but he couldn't find an appropriate full-time job. - Він був освіченою людиною й володів багатьма навичками, але не міг знайти пристойну роботу на повний робочий день.

«Educated» також може означати дію, що грунтується на конкретному досвіді, набутих знаннях: It was just an educated guess; he couldn't know it for sure. - Він просто здогадався про ие завдяки власному досвіду; він не міг знати точної відповідi.

Здатність об'єкта сприймати, інтелектуально обробляти та використовувати інформацію на практиці (capable of comprehending and implementing the knowledge) передається поняттями «understanding», «comprehensive», «conceivable» (рис. 5).

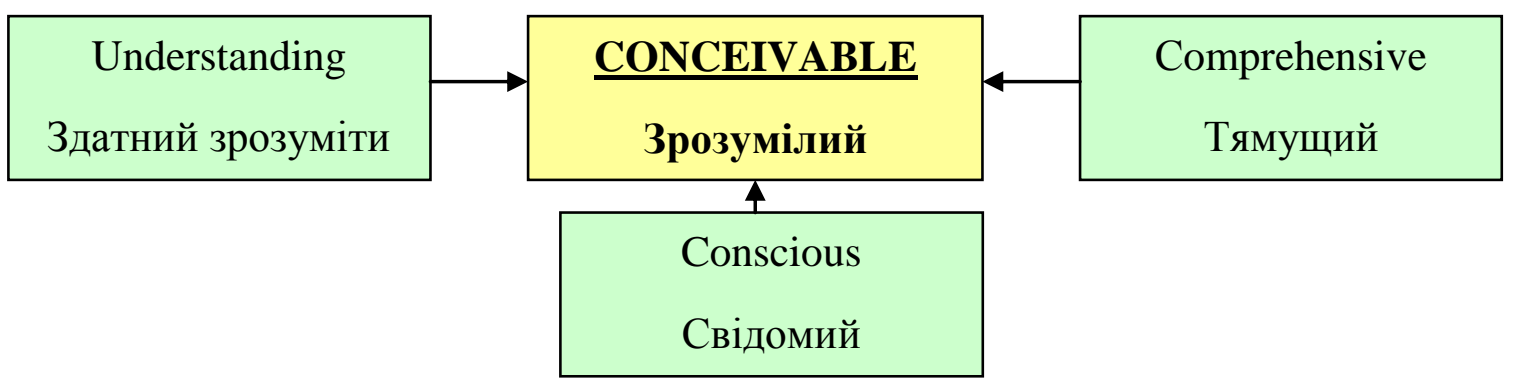

Рис. 5. Лексико-семантична група Conceivable

«Comprehensive» вказує на широку ментальну здатність сприймати інформацію: Comprehensive students reach high standards by working hard at each level of the school. - Taмymi студенти досягають високих стандартів, старанно працюючи на кожному етапі навчання.

«Understanding» характеризує людину обізнану, помірковану, розумну: $\mathrm{He}$ is an understanding man. - Він компетентна людина.

«Conceivable» додає до вищевказаних ознак наявність уяви, уміння не лише сприймати, але й переробляти інформацію, ретельно обдумувати: In order to avoid this problem we have to take every conceivable precaution. - Для уникнення цієї проблеми ми маємо вжити всхі можливих застережних заходів.

Також до цієї ЛСГ входять прикметники із семою «conscious». Вони позначають спроможність усвідомлювати та реалізувати знання: I am conscious of your great kindness to me. Я розумію, щзо ти зробив мені велику послугу.

Прикметники із загальною характеристикою «Rational» поділяються на ряди синонімів за ознаками «той, що вміс тверезо, логічно мислити», «розсудливий» (using reason or logic in thinking out a problem). В англійській мові ці поняття передаються семами «rational», «reasonable», «judicious», «practical» (рис. 6).

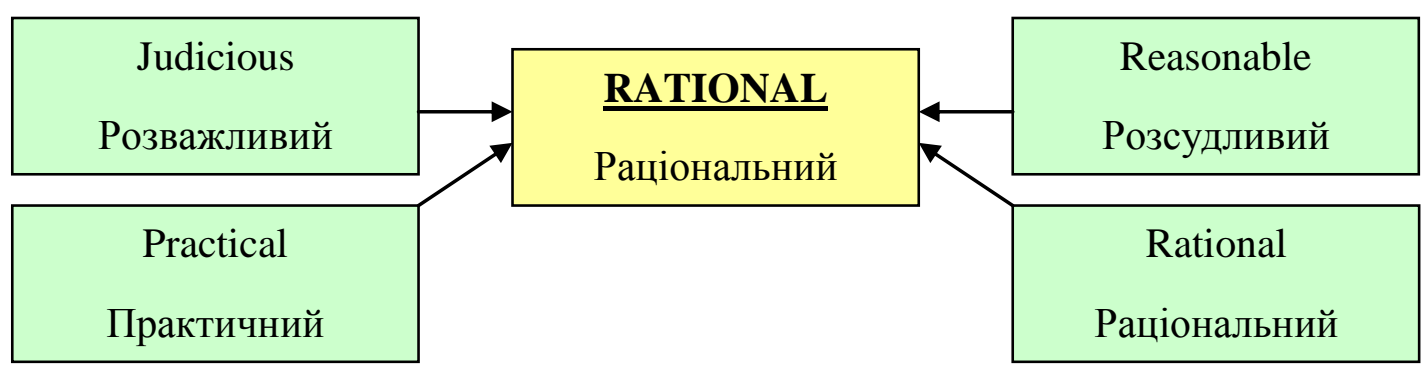

Рис. 6. Лексико-семантична група Rational 
«Judicious» указує на наявність збалансованого й мудрого судження та вміння його використовувати: It would be a judicious decision to remain silent. - Розумніше за все - зберігати тишу.

«Practical» означає вміння доцільно використати наявні знання: He is completely practical in his approach to business. - Він має розумний підхід до ведення бізнесу.

A practical advice - розумна, практична порада.

Обидві семи «јudicious» та «practical» передають уміння оцінити ситуацію й маніпулювати набутим досвідом.

«Reasonable» i «rational» уживаються для характеристики здорового глузду. «Rational»більш технічне та абстрактне поняття, завжди пов'язане із чистим розумом, та часто вживається для характеристики логічного мислення: Man is a rational being - Людина-розумна істота; $\boldsymbol{A}$ rational plan - розумний план.

«Reasonable» уключає більш прагматичний смисл простого здорового глузду: Let's be reasonable about this. -Давай будемо тверезо дивитися на це.

ЛСГ прикметників, що показують відсутність розумової здатності (Mental), можна поділити на такі смислові категорії: «insane (mad, crazy)»- стосовно хвороб, пов'язаних із роботою головного мозку (affected by mental illness); «inattentive, imageless» - відсутність уяви, уваги, розсіяність (not possessing attention or imagination); «slow»- що характеризує швидкість та якість розумової реакції (having dull mental responses) (рис. 7).

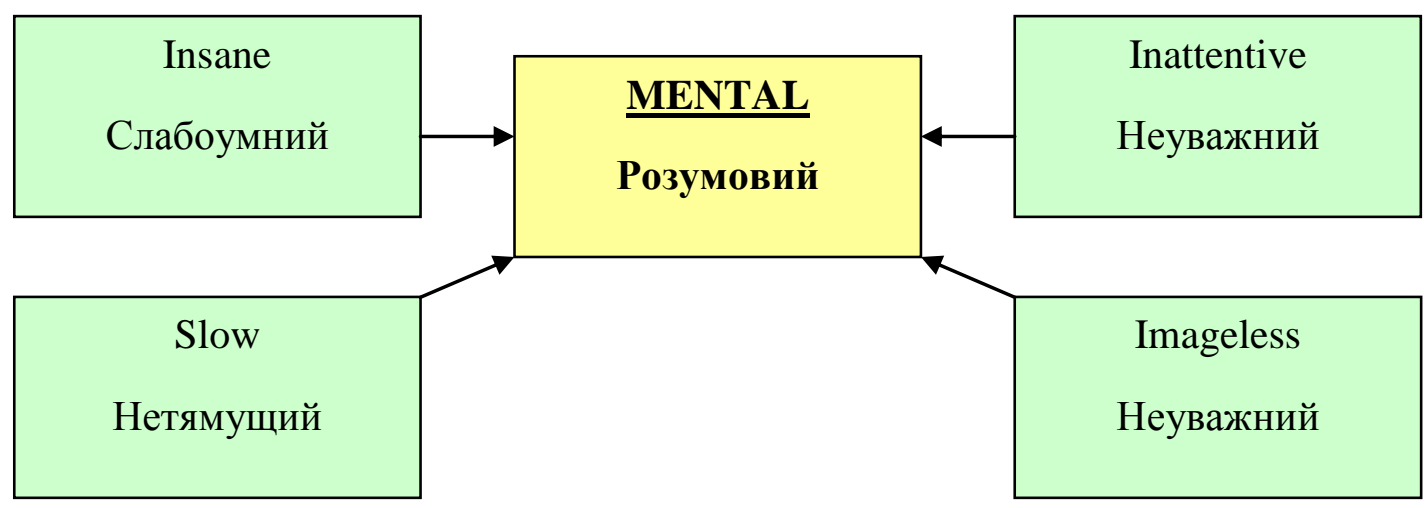

Рис. 7. Лексико-семантична група Mental

Прикметники із семою «іnsane» характеризують розумові відхилення та психічні хвороби: This woman was declared insane. - Цю жінку визнали психічно хворою.

«Insane» також може стосуватися продуктів інтелектуальної діяльності: A completely insane scheme to build a bridge between two mountains. - Безглуздий проєкт побудови мосту між горами; An insane risk - безглуздий ризик.

«Inattentive» указує на приділення недостатньої уваги через відсутність інтересу до чогось та розсіяність, недбалість: He was a completely gross, vulgar farmer, totally inattentive to appearances, and thinking of nothing but profit and loss. - Він був грубим і неотесаним фермером, який не приділяв ніякої уваги зовнішності й думав лише про прибутки та збитки.

«Slow» передбачає повільність розумової реакції та характеризує людину нетямущу, котра повільно думає: A slow thinker might be able to accomplish great things given enough time. Людина, яка думає повільно, здатна виконати все щэо завгодно, якщо для изього в неї буде достатньо часу.

I suppose I am a little slow on the uptake - Iноді до мене погано доходить.

Решта ЛСГ прикметників із негативною конотацією не мають такої розширеної структури, і фактично всі їхні складники пояснюються через слова-домінанти.

Прикметники із семою «stupid» указують на відсутність інтелекту, прийняття невиважених рішень, недоцільність, безглуздість чогось: That Smith must be blind or stupid to not realize he was asking for trouble with this kind of venture. - Сміт або сліпий або дурний, якщо він не може усвідомити, щзо, йдучи на иъю авантюру, він ризикує потрапити в неприємну ситуацію.

We were sitting in the sun grinning big stupid grins, not believing our luck. - Ми грілися на 
сонечку із дурнми посмішками на обличчях. Ми не могли повірити, щзо нам так пощастило.

«Unintellectual» указує на необізнаність, неосвіченість, недостатній інтелектуальний розвиток і навіть безкультурність, а також може підкреслювати, що предмет або явище не належать до інтелектуальної сфери: I may have misunderstood your thoughts, but I do agree that we Americans tend to take an unintellectual approach to life. - Можливо, я тебе неправильно зрозумів, але я не можу не погодитись, що у нас, американців, підхід до життя неінтелектуальний.

«Fool» стосується людини нерозсудливої, котра нездатна приймати виважені рішення: Humans are by their nature more fool than wise. - За своєю природою люди скоріше нерозсудливі, аніж мудрі; A fool behavior - нерозумна поведінка.

«Thoughtless» характеризує людину бездумну й безвідповідальну: Problems are still being experienced with thoughtless car owners parking on the pavements. - I досі існує проблема із безвідповідальними автовласниками, щчо паркуються на тротуарах.

«Ignorant» указує на незнання чогось, необізнанність, непоінформованість: The man is either totally ignorant of the facts or an abject liar. - Цей чоловік або не знає всіх нюансів справи, або жалюгідний брехун.

«Obscure» уживається на позначення незрозумілих предметів та явищ і вказує на необхідність володіння спеціальними знаннями, що доступні лише небагатьом: Unfortunately, due to numerous quirks of language and obscure allusions, the play is difficult to understand without assistance. - На жаль, через гру слів та загадкові натяки виставу важко зрозуміти без сторонньої оопомоги.

«Irrational» передбачає наявність розумових відхилень та використовується для підкреслення нелогічності чого-небудь: People under stress can be irritable, withdrawn, appear irrational, aggressive or even violent. - Люди в стані нервового напруження можуть бути дратівливими, замкнутими та здаватися нерачіональними, агресивними і навіть жорстокими; An irrational behavior - нерозважлива поведінка.

Як бачимо, групи 3 позитивною й негативною характеристикою відрізняються семантичними диференціаціями всередині кожної з них. Причому їх можна фактично вважати антонімічними.

Групи ад'єктивів з позитивним значенням не $є$ семантично гомогенними й поділяються на синонімічні ряди, домінанти. яких входять до тлумачення домінанти всієї групи, але їхні значення вужчі, специфічніші. Групи прикметників із негативною конотацією, навпаки, не мають сильно вираженого семантичного розгалуження та тому характеризуються більшою однорідністю.

Висновки. Виконаний аналіз дає змогу зробити висновок, що, оскільки процес мислення не $є$ за своєю сутністю однорідним, то в мовній площині він репрезентується різними семантичними категоріями, або лексико-семантичними групами, які виражають позитивні й негативні інтелектуальні властивості людини. За семантичними диференціаціями виокремлено рівну кількість груп з позитивною й негативною характеристикою. Лексико-семантичні групи 3 позитивною характеристикою представлені такими домінантами, як Clever - Розумний, Intellectual - Інтелектуальний, Wise - Мудрий, Thoughtful - Поміркований, Informed Поінформований, Conceivable - Зрозумілий, Rational - Раціональний. Лексико-семантичні групи 3 негативною характеристикою охоплюють такі домінанти, як Stupid - Дурний, Unintellectual Неінтелектуальний, Fool - Нерозсудливий, Thoughtless - Бездумний, Ignorant Непоінформований, Obscure - Незрозумілий, Irrational - Нераціональний). Кожна 3 груп має свою домінанту, яка об'єднує всі можливі семантичні компоненти цієї групи.

У результаті аналізу виокремлених лексико-семантичних груп установлено, що прикметники 3 негативною конотацією не мають сильно вираженого семантичного розгалуження, характеризуються більшою однорідністю, проте за кількісним складом не поступаються прикметникам із позитивною конотацією.

\section{References}

1. Verdieva, Zemfira. 2013. Semanticheskiye polya v sovremennom anglijskom yazike. Moskva: Vysshaya Shkola.

2. Gorokhova, Iryna. 2009. "Lessyko-semantychne pole diyesliv zi znachenniam rozumovoii diyalnosti". Naukovyi chasopys NPU imeni M. P. Dragomanova 9: 193-196. 
3. Dilai, Iryna. 2014. "Kohnityvni diyeslova v leksyko-semantychnii systemi angliiskoyi movy: istoriya ta perspektyvy doslidzhnnia". Visnyk Lvivskogo universytetu: seriia “Inozemni movy”. 22: 28-37.

4. Gulyga, Elena, \& Shendels, Yevgeniia. 1999. Grammatiko-leksicheskiya polia v sovremennom nemetskom yazyke. Moskva: Prosveshcheniye.

5. Kravtsova, Nadezhda. 2008. Otsenochnaya kategorizatsiia intellektualnykh sposobnostej cheloveka $v$ sovremennom angliyskom yazyke. Tambov.

6. Nizhegorodtseva-Kirichenko, Larissa. 2000. Leksiko-semanticheskoe pole "Intellktualnaya deyatelnost": opyt kontseptualnogo analiza (na materiale sushchestviteknykh sovremennogo anglijskogo yazyka). Kiev.

7. Novikov, Lev. 2002. "Semanticheskoye pole kak leksicheskaya kategoriia". Teoriia polia v sovremennom yazykoznanii 1: 3-7.

8. Schneider, Edgar. 1988. Studien zur Lexikalischen Semantik der Mentalen Verben des Englischen. Tübingen: Niemeyer.

Корнева Зоя. Актуализация английских прилагательных, обозначающих мыслительные категорий и особенности их представления в украинском языке. В статье рассматриваются семантические характеристики английских прилагательных для обозначения интеллектуальных свойств и результатов умственной деятельности личности, ядром лексико-семантического поля которых выступает понятийная категория «мышление». Английский язык, как и многие другие, накопил существенный лексический потенциал для разных аспектов интеллектуальной силы и когнитивных умений. В лингвистическом смысле охарактеризовать его можно на основе анализа определенного лексико-семантического поля. Для выявления словесных характеристик прилагательных, характеризующих позитивные и негативные интеллектуальные свойства были определены состав и структура соответствующего лексико-семантического поля, анализируется семантическая структура доминант выделенных лексико-семантических групп, а также особенности отражения конституентами группы интеллектуальных свойств. По результатам анализа установлено, что оно состоит из соответствующих лексико-семантических групп, каждая из которых представлена полярными семантическими доминантами. Группу прилагательных с положительной коннотацией представляют такие семантические доминанты, как clever, intellectual, wise, thoughtful, informed, conceivable, rational, a с отрицательной - как stupid, unintellectual, fool, thoughtless, ignorant, obscure, irrational. Путем анализа семантической структуры прилагательных для обозначения мыслительных категорий установлено, что прилагательные с отрицательной коннотацией не имеют сильно выраженного семантического разветвления, характеризуются большей однородностью, однако по количественному составу не уступают прилагательным с положительной коннотацией. Изучение особенностей представления ментальных прилагательных на украинском языке позволило установить, что их перевод зависит от сочетаемости с другими лексическими единицами и языкового контекста. Предпринятое исследование лексико-семантического поля прилагательных для обозначения мыслительной деятельности человека служит основой для объяснения явлений полисемии, синонимии и антонимии, создания тематических словарей-тезаурусов.

Ключевые слова: прилагательные английского языка, обозначение мыслительной деятельности, лексикосемантическое поле, семантическая доминанта, перевод на украинский язык.

Kornieva Zoia. Actualization of English Adjectives Denoting Mental Categories and Specificity of their Translation into Ukrainian. The article is focused on the consideration of the semantic characteristics which are manifested by the lexical semantic field constituted by the adjectives of contemporary English. The English language, like many others, has accumulated significant lexical potential for various aspects of intellectual strength and cognitive skills. In a linguistic sense, it can be characterized based on the analysis of a certain lexical and semantic field. To identify the verbal characteristics of the adjectives that characterize positive and negative intellectual properties, the composition and structure of the corresponding lexical-semantic field have been determined, the semantic structure of the dominants of the selected lexicalsemantic groups have been analyzed along with the peculiarities of their reflection in the constituents of the field. It has been identified that the field under study consists of the lexical semantic groups each of which is represented by a specific semantic subcategory being of positive or negative connotation (Mental, Clever, Intellectual, etc.). The carried out analysis revealed the semantic structure of the mental adjectives, peculiarities of their combinatory properties as well as regularities of their translation into Ukrainian. It has been found out that the semantic structure of adjectives with negative connotation is not as ramified as the one of the positive connotation, though their number is nearly the same. It has also been identified that translation of mental adjectives into Ukrainian depends on their combinatory power and verbal context. The study of the intellect notional category helps understand how words and their multiple meanings are stratified within the lexical semantic field, providing an explanation for the phenomena of polysemy and synonymy/antonymy inherent in the units of the lexical semantic field, for creating thematic dictionaries-thesauri.

Key words: English adjectives, mental activities, lexical semantic field, semantic subcategory, translation into Ukrainian. 